\title{
THE SÃO GERALDO DO ARAGUAIA OPAL DEPOSIT, PARÁ, BRAZIL
}

\section{TAYLOR ARAÚJO COLLYER ${ }^{1}$ AND BASILE KOTSCHOUBEY ${ }^{2}$}

\begin{abstract}
The São Geraldo do Araguaia Opal Deposit is situated in the northern part of the Araguaia Belt and consists of small pockets and anastomosed opal veinlets, which are enclosed in the inner part of a sub-meridian, up to $6 \mathrm{~m}$ thick, highly brecciated and roughly zoned vein. This vein is composed of jasper opal with massive quartz margins and occurs in biotite schists of the Xambioá Formation (Estrondo Group) of Upper Proterozoic age. White to pinkish, fire and boulder opal varieties were identified in this deposit. Although the age of the quartz of the border is certainly Precambrian, jasper opal and the diverse opal types are more recent. It is thought that they were mainly formed in JurassicCretaceous times, when distension tectonic and reactivation of Precambrian discontinuities, related to the evolution of the Parnaíba Basin and the opening of the Atlantic Ocean, took place and induced low temperature hydrothermalism. However, the more noble opal varieties apparently are more recent, related to Cenozoic supergene processes.
\end{abstract}

Keywords: opal, jasper opal, hydrothermalism, supergene alteration, Araguaia Belt, state of Pará.

INTRODUCTION Opal has been known in Brazil for decades and the most important and famous deposits in Brazil are situated near Pedro II, in the state of Piauí. Other occurrences are located close to Lajeado, in the state of Rio Grande do Sul, near Boa Nova and Boquira, in the state of Bahia, and Currais Novos, in the state of Rio Grande do Norte. A new opal occurrence, recently discovered at the Manoel Ambrósio Ranch, in the neighborhood of São Geraldo do Araguaia, southeastern part of the state of Pará (Collyer et al. 1991) has been studied by Collyer (1999).

GEOLOGICAL SETTING The São Geraldo do Araguaia Opal Deposit is situated in the northern part of the Araguaia Belt of Brasiliano age (Fig. 1). The main lithostratigraphic units in this region are the basement represented by the Colméia Complex of Archean age and the supracrustal rocks of the Estrondo Group, a subdivision of the Baixo Araguaia Supergroup of Upper Proterozoic age (Dall'Agnol et al. 1988). The Colméia Complex is found in the core of dome structures (Xambioá and Lontra sectors) and is essentially made up of trondhjemitic gneisses, migmatites and amphibolites. The Estrondo Group is predominantly of sedimentary origin with some volcanic contribution and was metamorphosed in the greenschist to middle amphibolite facies. It is subdivided in two units, the Morro do Campo and the Xambioá Formations. The former unit unconformably overlies the basement rocks and is composed of quartz-muscovite schists, quartzites, kyanite quartzites and subordinate amphibolites and polymictic conglomerates. The overlying Xambioá Formation consists of mica schists, graphite schists, feldspathic schists, garnet, kyanite and staurolite schists and amphibolites. Dolerite dykes and small serpentinite and gabbro bodies are emplaced into the basement as well as in the supracrustal formations. Granitic bodies are intrusive into the Estrondo Group and mainly consist of fine to medium-grained alkaligranite. Aplite and pegmatite lenses and veins, and hydrothermal quartz veins complete the lithologic framework of this sector of the Araguaia Belt (Macambira and Kotschoubey 1981, Santos et al. 1984)

According to Hasui \& Costa (1990) the Araguaia Belt is derived from a half-graben structured basin which later underwent intense inversion. The compressive phase resulted in an intense ductile shear deformation related to sub-horizontal mass transport towards the NNW. This major tectonic phase is thought to have occurred during the Brasiliano orogenic cycle. Stretching, overthrusting and subsequent folding marked the regional tectonic evolution. Basement and/or granitic diapirism coeval with the tangential deformation and regional metamorphism (Santos et al. 1984) possibly originated the dome structures situated along the eastern margin of the belt. During the Paleozoic, NW-SE tensional movements related to the opening of the Atlantic ocean were responsible for the early evolution of the Parnaíba Basin and resulted in the formation of N-S oriented normal faults, essentially by reactivation of Precambrian structures (Costa $e t$ al. 1991a). A new reactivation of the normal faults occurred from the Upper Jurassic to the Late Cretaceous, caused by ENE-WSW tensional movements related to the development of the Equatorial Atlantic Ocean (Costa et al. 1991b).

GEOLOGY OF THE DEPOSIT In the Manoel Ambrósio Sector, mainly mica schists and kyanite-mica schists of the Xambioá

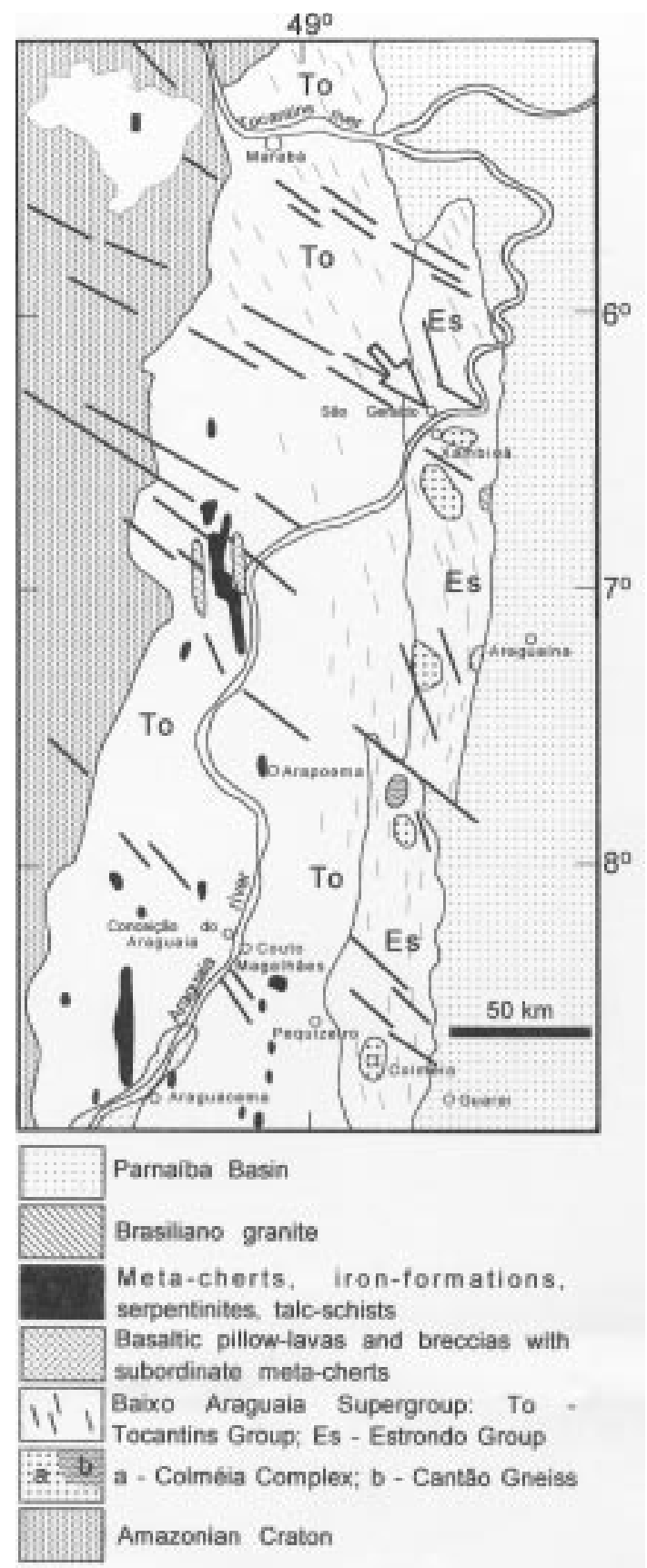

Figure 1 - Geological sketch of the Araguaia Belt and location of the São Geraldo Opal Deposit.

1 - Secretaria de Indústria, Comércio e Mineração do Estado do Pará - SEICOM. Belém, Pará, Brazil E-mail: mineracao@ seicom.pa.gov.br

2 - Centro de Geociências, Universidade Federal do Pará. Campus universitário do Guamá, Caixa Postal 1611, CEP 66075-110, Belém, Pará, Brazil. Fax: (091)211-1478. E-mail: basile@ufpa.br. 
Formation occur. These rocks show compositional layering parallel to the schistosity and a low-angle strain lineation trending NNW-SSE and dipping to the east. Quartz veins are frequent in this area. The opal-bearing vein, approximately $3 \mathrm{~km}$ long, up to $6 \mathrm{~m}$ in thickness and trending $\mathrm{N} 10^{\circ} \mathrm{W}$, stands out in this geological setting.

Mica schists consist of quartz, biotite, and muscovite with subordinate plagioclase, kyanite, epidote, garnet and opaque minerals. These rocks exhibit a marked schistosity and, locally, crenulation folding. Pervasive hydrothermal alteration is not observed in these schists at the contact with the vein. Only thin quartz veinlets, both discordant and concordant with the schistosity, mark the border zone. The vein itself shows a rough zoning (Fig. 2). An approximately 0.5$\mathrm{m}$ thick outer zone is composed of massive and fractured milky quartz. Partially martitized, up to $15 \mathrm{~cm}$ in diameter magnetite nodules and aggregates are enclosed in quartz at the contact with the host rock. Millimetric to centimetric angular schist inclusions also occur in this zone.
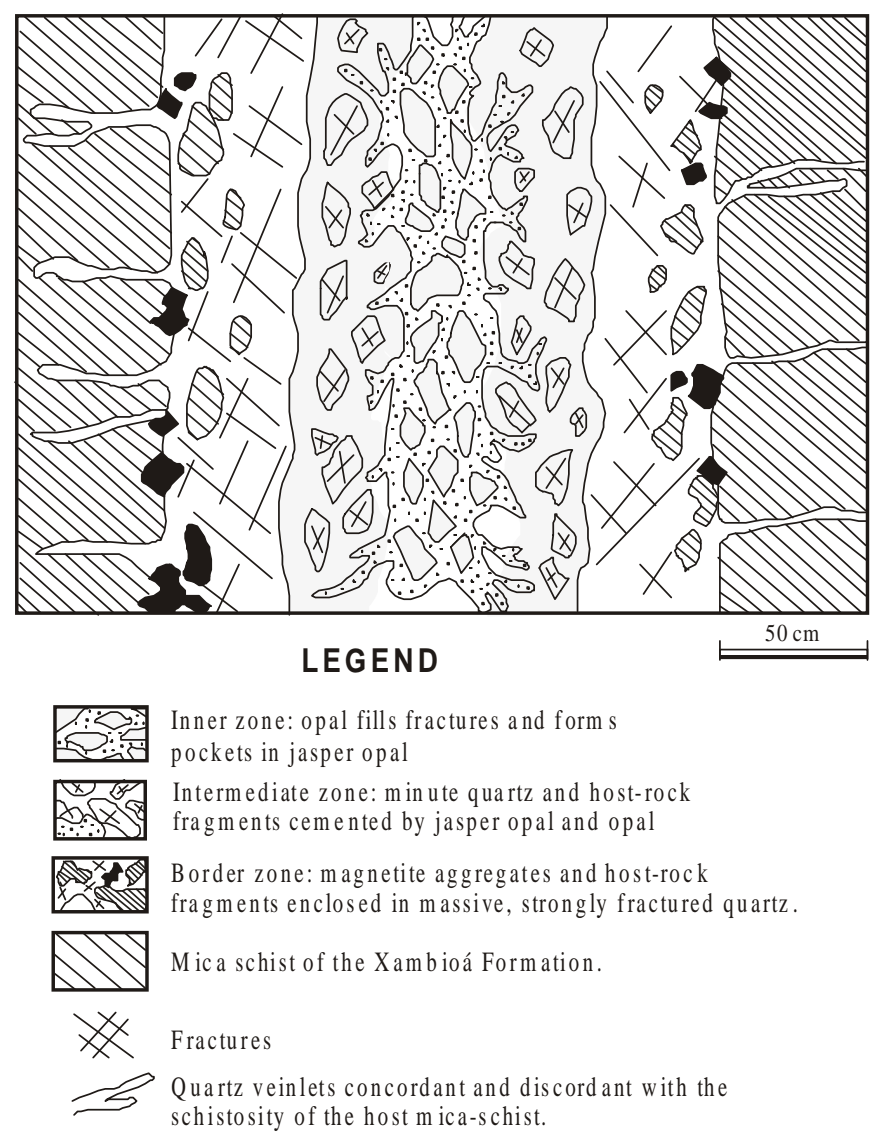

Figure 2 - Schematic section of the São Geraldo opal-bearing vein showing its rough zonation.

Primary aqueous, tri-phase (S-L-G) and aqueous-carbonic bi-phase (L-G) fluid inclusions were identified and studied in this outer quartz zone. The tri-phase fluid inclusions contain halite crystals and revealed a $\mathrm{H}_{2} \mathrm{O}-\mathrm{NaCl}-\mathrm{KCl}$ composition, while salinity is higher than 26 weight $\% \mathrm{NaCl}$ and a minimum trapping temperature from 232 to $310^{\circ} \mathrm{C}$. The bi-phase inclusions showed a $\mathrm{H}_{2} \mathrm{O}-\mathrm{CO}_{2}-\mathrm{NaCl}$ composition with a salinity of about 18 weight $\% \mathrm{NaCl}^{2}$ and a minimum trapping temperature from 220 to $245^{\circ} \mathrm{C}$.

An intermediate zone consists essentially of yellowish to reddish ochre jasper opal and displays a markedly brecciated texture (Fig. 3A). Sub-millimetric to millimetric, angular quartz inclusions are commonly enclosed within this jasper opal matrix. In these inclusions, primary bi-phase aqueous (L-G) fluid inclusions indicate a $\mathrm{H}_{2} \mathrm{O}-\mathrm{FeCl}_{2}$ $\mathrm{NaCl}$ composition, very low salinity (from 0.88 to 3.71 weight $\%$ $\mathrm{NaCl}$ ) and low minimum trapping temperature (from 110 to $145^{\circ} \mathrm{C}$ ). Irregular fractures crosscutting jasper opal are filled with white to pinkish opal and minor fire opal.

In the inner zone, jasper opal still predominates but the brecciated texture is more pronounced than in the intermediate one. Different

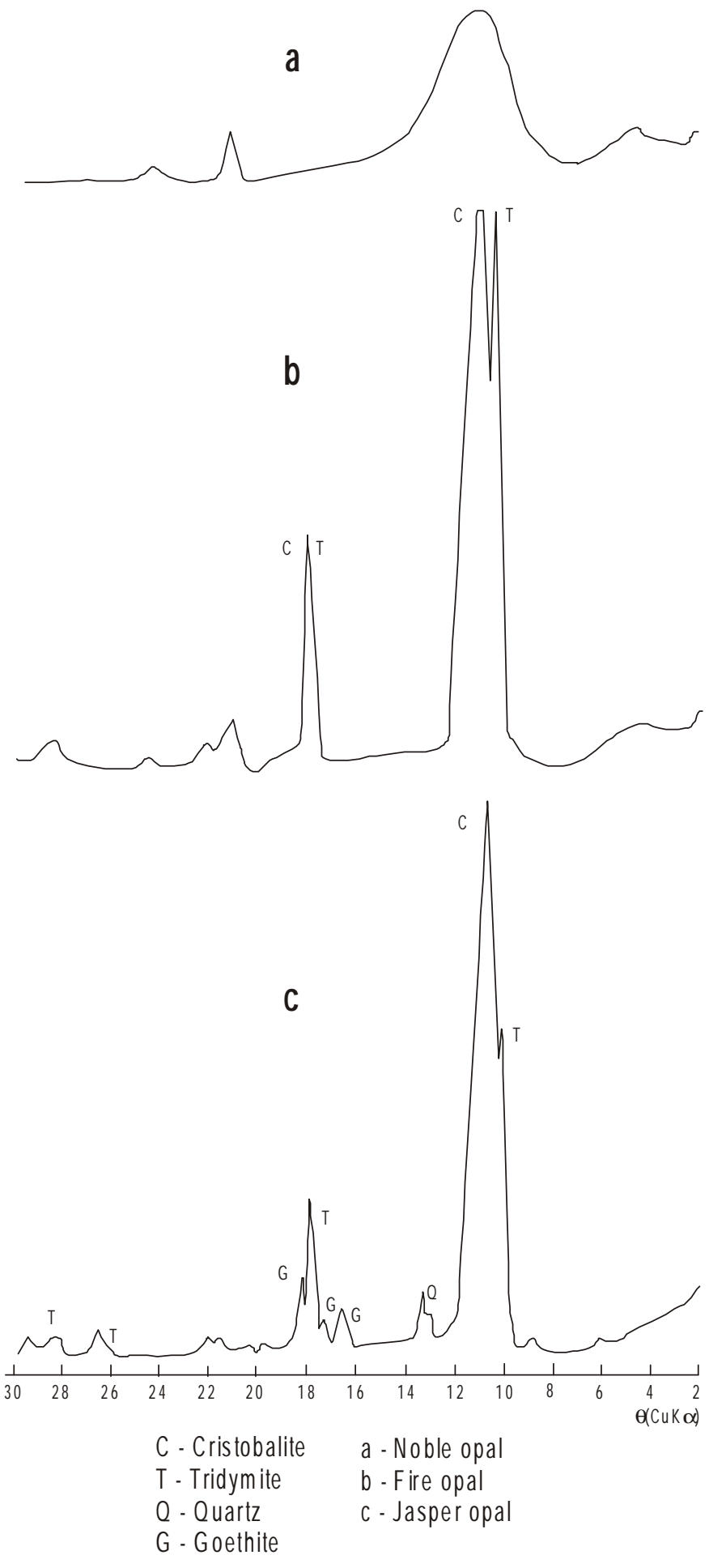

Figure 3 - Photographs and photomicrographs of opal and jasper opal from the São Geraldo Deposit. (A) Intermediate zone: highly brecciated jasper opal with opal filling fractures, (B) Inner zone: Massive, light-colored opal enclosing small angular jasper opal fragments, (C) Acicular rutile crystals displaying a fan-like arrangement enclosed in jasper opal, (D) Outer border of the intermediate zone: minute quartz fragments enclosed in jasper opal, $(E)$ Onyx: Microcrystalline quartz and fiber-radial spherulitic chalcedony $(F)$ Noble white opal: slightly deformed and coalescent spherules of amorphous silica; note the high porosity of opal.

types of light-colored opal fill up fractures forming veins and anastomosed veinlets within the jasper opaline mass. Locally occur up to 40-cm large pockets of white and fire opal with less abundant noble opal (Fig. 3B). Laterally, jasper opal and opal zones commonly grade to black or gray veined onyx. 
Table 1 - Principal physical, mineralogical and chemical characteristics of the jasper opal and opal from the São Geraldo do Araguaia Deposit.

\begin{tabular}{|c|c|c|c|c|c|}
\hline OPAL TYPE & COLOR and TRANSPARENCY & $\begin{array}{l}\text { TRACE } \\
\text { COLOR }\end{array}$ & $\begin{array}{l}\text { HARDNESS } \\
\text { (Mohs scale) }\end{array}$ & $\begin{array}{l}\text { DENSITY } \\
\left(\mathrm{g} / \mathrm{cm}^{3}\right)\end{array}$ & FRACTURE \\
\hline White noble opal & $\begin{array}{lll}\text { White with opalinization } & \text { (transparent to } \\
\text { translucent) }\end{array}$ & White & 6 & 1.99 & Conchoidal \\
\hline Firy opal & $\begin{array}{l}\text { Yellow, orange, colorless, white and creme } \\
\text { (transparent, translucent and opaque) }\end{array}$ & White & 6 & 1.99 to 2.00 & Conchoidal \\
\hline Jasper opal & $\begin{array}{l}\text { Light to dark, yellowish to reddish ochre } \\
\text { (opaque) }\end{array}$ & White & 6 & 2.00 to 2.10 & Conchoidal \\
\hline
\end{tabular}

\begin{tabular}{|l|c|c|c|l|}
\hline \multicolumn{1}{|c|}{ OPAL TYPE } & $\begin{array}{c}\text { REFRACTIVE } \\
\text { INDEX }\end{array}$ & $\begin{array}{c}\text { OPTICAL ABSORPTION } \\
\text { SPECTRUM }(\mathrm{nm})\end{array}$ & \multicolumn{1}{c|}{ FLUORESCENCE } & \multicolumn{1}{c|}{ INCLUSIONS } \\
\hline White noble opal & 1.440 & & Bluish white to greenish brown & Carbonaceous matter \\
\hline Firy opal & 1.445 to 1.450 & $700,640,590,400$ & Greenish to greyish brown & Rutile, hematite \\
\hline Jasper opal & - & - & - & $\begin{array}{l}\text { Rutile, quartz, sericite, } \\
\text { hematite }\end{array}$ \\
\hline
\end{tabular}

\begin{tabular}{|c|c|c|c|c|c|c|c|c|}
\hline OPAL & \multicolumn{7}{|c|}{ CHEMICAL COMPOSITION (in weight $\%$ on dehydrated base) } & $\mathrm{H}_{2} \mathrm{O}$ CONTENTS \\
\hline & $\mathrm{SiO}_{2}$ & $\mathrm{Fe}_{2} \mathrm{O}_{3}$ & $\mathrm{Al}_{2} \mathrm{O}_{3}$ & $\mathrm{CaO}$ & $\mathrm{MgO}$ & $\mathrm{Na}_{2} \mathrm{O}$ & $\mathrm{TiO}_{2}$ & \\
\hline $\begin{array}{l}\text { White noble } \\
\text { opal }\end{array}$ & $>99$ & 0.02 & 0.45 & 0.04 & 0.04 & 0.03 & 0.02 & 2.8 to 5.0 \\
\hline Firy opal & 98 to 99 & 0.02 & 0.70 & 0.04 & 0.03 & 0.94 & 0.02 & $\begin{array}{l}\text { Yellow and creme: } \\
4.2 \text { to } 8.5 \\
\text { White: up to } 19.8\end{array}$ \\
\hline Jasper opal & 85 to 93 & 6.80 to 14.60 & 0.53 to 0.81 & $\leq 0.02$ & 0.02 to 0.04 & 0.01 to 0.03 & 0.03 to 0.04 & - \\
\hline
\end{tabular}

MINERALOGY AND GEOCHEMISTRY OF OPAL AND JASPER OPAL In thin sections, jasper opal is pinkish to light reddish-gray. It is colloform, banded in places or has vesicular textures. The most common inclusions are minute angular to rounded quartz grains, small prismatic kyanite crystals and tabular crystals of green biotite partially altered to chlorite (Fig. 3D). In places, jasper opal contains abundant acicular rutile crystals disposed following a roughly radial, fan-like pattern (Fig. 3C). Onyx is essentially composed of microcrystalline quartz with fiber-radial, spherulitic chalcedony forming countless pockets and veinlets (Fig. 3E).

Regardless of its macroscopic characteristics, the light-colored opal appears as an almost colorless, commonly slightly pinkish, yellowish or light gray homogeneous mass and shows lower refractive indices than jasper opal and quartz (from 1.440 to 1.460). Irregular, in places scarred fractures and rare quartz and jasper opal inclusions locally occur. The density of opal and its contents of absorbed water vary with the type (Table 1).

X-ray diffraction analyses revealed that jasper opal has a homogeneous composition and mainly consists of cristobalite with subordinate tridymite and variable amounts of iron hydroxide (Fig. 4). On the other hand, light-colored opal varies significantly in composition and degree of crystallization of its components (Fig. 4). While the noble white variety is nearly amorphous with only traces of cristobalite and, thus, is similar to the opal A type, the common fire and white to pinkish varieties are rich in cristobalite and tridymite and correspond to opal C-T (Deer et al. 1992). SEM analyses show that noble white opal is essentially composed of minute spherules ( $£$ $200 \mathrm{~mm}$ ) of amorphous silica, arranged in a fairly regular pattern. The spherules are generally well preserved though commonly coalescent and slightly deformed by stress (Fig. 3F). The inter-spherule pores are in part filled with carbonaceous matter.

The São Geraldo opal, as a rule, contains very low amounts of aluminum, iron and other elements, while the jasper opal is strongly enriched in iron, though its composition for most other elements is generally similar to that of light-colored opal (Table 1).

EVOLUTION OF THE VEIN AND ORIGIN OF OPAL It is clear that quartz from the margins and the intermediate zones was formed much earlier than jasper opal and opal, and is certainly of Brasiliano age. It appears likely that the hydrothermal process started with injection of highly saline ( $\mathrm{NaCl}$ rich) aqueous fluids of magmatic origin, at temperatures up to $310^{\circ} \mathrm{C}$. Then were injected somewhat cooler (up to $245^{\circ} \mathrm{C}$ ) and less saline fluids of predominantly metamorphic origin, which is suggested by the aqueous-carbonic nature of the solutions. Finally, weakly saline and low-temperature fluids, mainly composed of meteoric waters, originated quartz of the intermediate zone and marked the end of the Precambrian evolution of the vein.

The metastable nature of the cristobalite-tridymite association and of the nearly amorphous opal which form the greater part of the vein is incompatible with the Precambrian age of the quartz margins and the metasedimentary host rocks. In fact, opal is never very old and, with time, it naturally evolves to chalcedony or very fine-grained quartz. Therefore, it seems likely that jasper opal and the light-colored opal types were formed in relatively recent Phanerozoic time.

In terms of genetic processes, the close relationship of opal with a pre-existing hydrothermal quartz vein and the brecciated texture and rough zoning of the present-day filonian body suggest a hydrothermal origin. In the absence of any apparent relationship with Phanerozoic magmatism, it seems more likely that the hydrothermal process responsible for the opal formation was related to some stage of the Parnaiba Basin evolution, when N-S Precambrian fractures were reactivated, normal faults were formed and extension took place. Thus, it is suggested that this hydrothermal activity occurred in the period from Late Jurassic to Late Cretaceous, when the opening of the Equatorial Atlantic Ocean resulted in intense tensional movements in the Araguaia Belt Domain (Costa et al. 1991b). Low-temperature, silicarich hydrothermal solutions, possibly of meteoric derivation and originated at depth within the Estrondo Group or even the gneissic basement, were injected, in several pulses, into the reactivated fracture. Thus, quartz at first, then more recently deposited jasper opal were affected by intense fracturing. With fluid cooling, silica was deposited initially as jasper opal, then as light-colored opal varieties.

Although hydrothermal alteration appears to be the most important process in opal formation, the contribution of supergene alteration cannot be discarded. In fact, it is quite possible that, during the Cenozoic, downward percolation of surface waters resulted in the partial dissolution of previously precipitated opal, the remobilization of silica and its re-precipitation as nearly amorphous, noble opal in fractures and other cavities. 

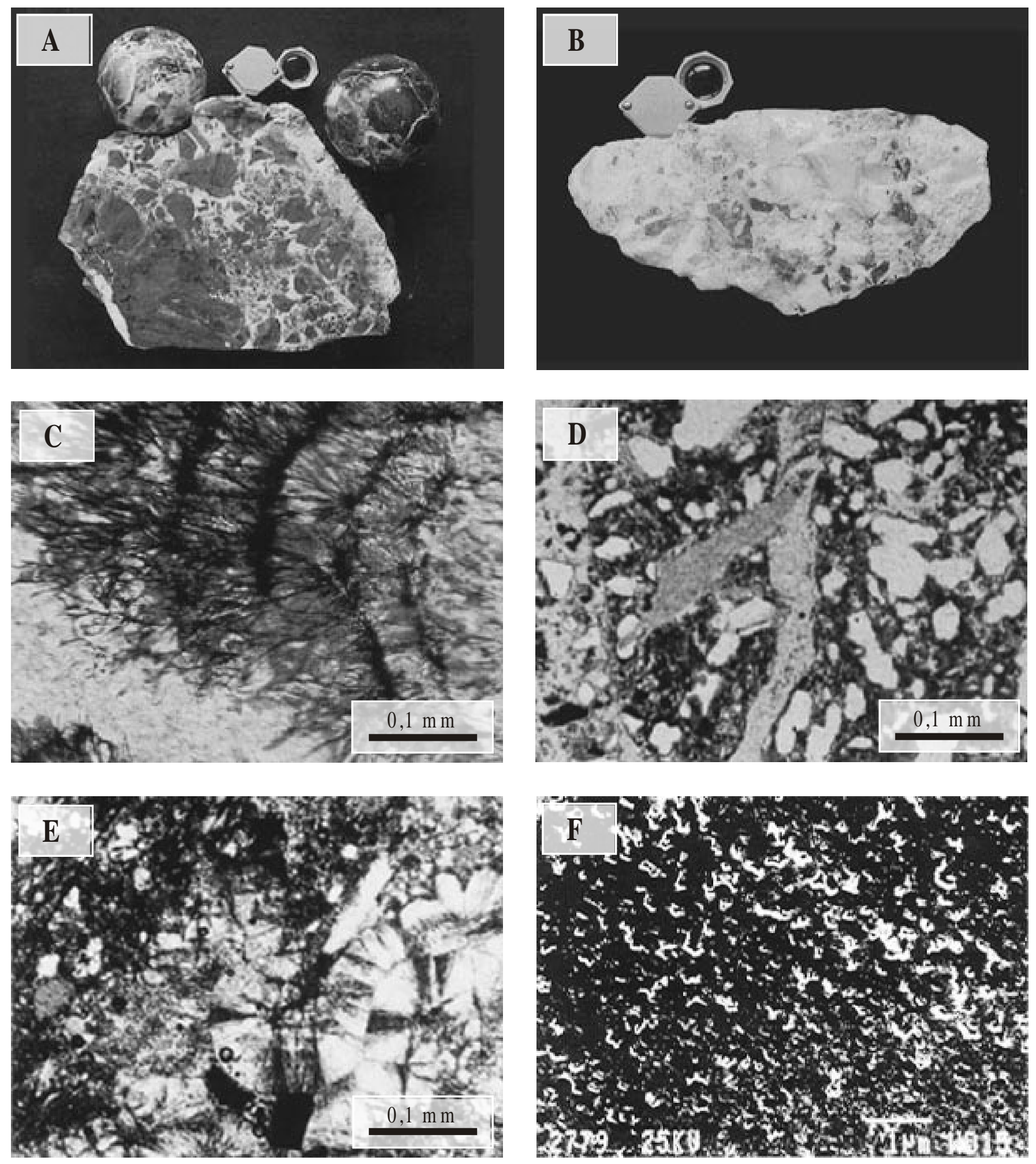

Figure 4 - X-ray diffractograms for noble white opal, fire opal and jasper opal from the São Geraldo Deposit.

CONCLUSIONS The São Geraldo do Araguaia Deposit consists of noble white, white to pink, fiery and boulder opal varieties, which fill up veinlets and pockets in the inner part of a large vein, hosted by biotite schists of the Xambioá Formation. The vein is mainly composed of jasper opal and displays a rough zonation due to the presence of quartz borders, which are thought to be remains of a former, Precambrian hydrothermal vein. The more common opal varieties are composed of cristobalite and tridymite in different proportions, while the noblest varieties consist of nearly amorphous silica.

It is likely that opal as well as the host jasper opal were formed in Jurassic-Cretaceous time and resulted from low temperature hydrothermalism caused by tectonism and reactivation of former fractures related to the opening of the Atlantic Ocean. After being mobilized at depth, silica precipitated as opal and jasper opal closer to the surface. However, recent supergene alteration probably played the decisive role in the formation of noble opal varieties.

Aknowledgments To IDESP, CNPq, FINEP for financial support and the Centro de Geociências/UFPA for analytical assistance, to Dr. C.A.R. Albuquerque for help with English language and comments on the manuscript, and to two referees of RBG for the critical review of the manuscript. 


\section{References}

Collyer T. A. 1999. Mineralizações de caráter gemológico (opala, ametista, quartzo tricolor, quartzo rutilado e a clorita) da região de São Geraldo do Araguaia (PA) e Xambioá (TO): Caracterização e gênese. Centro de Geociências, Universidade Federal do Pará, Doctor Thesis, $216 \mathrm{p}$.

Collyer T. A., Rodrigues E. G., Machado J. M. L., Granjeiro I. 1991. Mapa gemológico e de pedra ornamental do estado do Pará. In: SBG/Núcleo Norte, Simpósio de Geologia da Amazônia., 3, Belém, Anais, Anexos.

Costa J. B. S., Borges M. S., Igreja H. L.S., Hasui Y. 1991a. Aspectos da evolução tectônica da Bacia do Paraíba e sua relação com o arcabouço pré-cambriano. In: SBG, Simpósio Nacional de Estudos Tectônicos,.3, Rio Claro, Boletim, 96-98

Costa J. B. S., Igreja H. L. S., Borges M.S., Hasui. Y. 1991b. Aspectos estruturais da tectônica mesozóica do Brasil Setentrional. In: SBG/Núcleo Norte, Simpósio de Geologia da Amazônia, 3, Belém, Anais, 166-178

Dall'Agnol R., Teixeira N. P., Macambira J. B., Kotschoubey B., Gorayeb P. S., Santos M. D. 1988. Petrologia dos gnaisses e micaxistos da porção norte da Faixa de Dobramentos Araguaia, Goiás, Brasil. In: SBG, Congresso Latino-Americano de Geologia, 7, Belém. Anais, 1-19
Deer W. A., Howie R. A., Zussman J. 1992. An introduction to the rock-forming minerals. 2 ed. London, Longman Scientific \& Technical, 696 p.

Hasui Y and Costa J. B S. 1990. O Cinturão Araguaia: um novo enfoque estrutural estratigráfico. In: SBG, Congresso Brasileiro de Geologia, 34, Natal, Anais, 7:3450-

Macambira J. B. and Kotschoubey B. 1981. O magmatismo ácido na região da braquianticlinal do Lontra-GO. In: SBG/Núcleo Centro-Oeste, Simpósio de Geologia do Centro-Oeste, 1, Goiânia, Anais, 555-564

Santos M. D., Macambira J. B., Kotschoubey B. 1984. Uma proposta para a origem das braquianticlinais de Xambioá e Lontra (GO): possíveis domos gnáissicos. In: SBG, Congresso Brasileiro de Geologia, 33, Rio de Janeiro, Anais, 7:3400-3434

Contribution IGC-116 Received March 1, 2000
Accepted for publication May 22, 2000 